\title{
УДОСКОНАЛЕННЯ ЗАСВОСННЯ ПРАКТИЧНИХ НАВИЧОК І МЕТОДИК СТУДЕНТАМИ ТА ЛІКАРЯМИ-ІНТЕРНАМИ - ВАЖЛИВА СКЛАДОВА КАДРОВОЇ ПЕРЕБУДОВИ ПЕРВИННОЇ ЛАНКИ МЕДИЧНОЇ ДОПОМОГИ НАСЕЛЕННЮ УКРАЇНИ
}

\author{
О. П. Волосовець ${ }^{1}$ Ю. С. П'ятницький ${ }^{1}$, І. С. Вітенко ${ }^{2}$, І. В. Мельник ${ }^{2}$,
} Р. А. Стецюк ${ }^{2}$

${ }^{1}$ Міністерство охорони здоров'я України,

${ }^{2}$ Центральний методичний кабінет з вищої медичної освіти МОЗ України

\section{IMPROVEMENT OF ACQUIRING OF PRACTICAL SKILLS AND METHODS BY STUDENTS AND DOCTORS-INTERNS - THE IMPORTANT COMPONENT OF STUFF RE-BUILDING OF PRIMARY LINK OF MEDICAL CARE FOR POPULATION OF UKRAINE}

\author{
O. P. Volosovets ${ }^{1}$, Yu. S. Pyatnytskyi ${ }^{1}$, I. S. Vitenko², I. V. Melnyk ${ }^{2}$, R. A. Stetsiuk ${ }^{2}$ \\ ${ }^{1}$ Ministry of Public Health of Ukraine, \\ ${ }^{2}$ Central Methodical Cabinet on Higher Medical Education of MPH of Ukraine
}

\begin{abstract}
У статті висвітлюється необхідність вдосконалення навчально-методичного забезпечення підготовки лікарів “Загальної практики - сімейної медицини”, зокрема впровадження Наскрізної програми підготовки студентів медичних факультетів та лікарів-інтернів для оволодіння практичними навичками та методиками, необхідними для роботи на посадах лікарів за спеціальністю “Загальна практика - сімейна медицина", як важливої складової покращання практичної підготовки лікарів первинної ланки медико - профілактичної допомоги населенню.
\end{abstract}

The article adduces the necessity of educational and methodical supply of doctors' training on "General practice - family medicine" in particular the introduction of Continuous Program of students' training of medical faculties and doctors-interns for mastering of practical skills and methods, necessery for the work of doctors on the speciality "General Practice-family Medicine" as an important part of improvement of practical doctors' training of the primary link of medical and prophylactic care for population.

Вступ. Світовий досвід удосконалення системи вищої медичної освіти свідчить, що тільки поєднання якісних змін кадрового, матеріально-технічного та методичного забезпечення додипломного та післядипломного етапів підготовки фахівців-медиків є основою для впровадження в Україні нової євроінтеграційної системи підготовки та вдосконалення лікарів, які б стали конкурентоспроможними на світовому ринку праці [6].

Основна частина. Забезпечення безперервності та ступеневості медичної освіти згідно із стандартами Всесвітньої федерації медичної освіти було рекомендовано у рішенні Всеукраїнської наукової навчально-методичної конференції “Нові напрямки впровадження кредитно-модульної системи організації навчального процесу у вищих медичних і фармацевтичному навчальних закладах України III-IV рівнів акредитації' (12-13 травня 2011 р., м. Тернопіль) [2]. Серед структурних змін у наданні медичної допомоги в Україні первинна медико-санітарна допомога $\epsilon$ пріоритетною, i без удосконалення якості підготовки на всіх етапах становлення лікаря загальної практики - сімейного лікаря та відповідної мотивації неможливо здійснити реформування галузі.

На виконання доручення Кабінету Міністрів України від 23 листопада 2010 р. № 69/158/1/1-10 до доручення Президента України від 19 листопада 2010 р. № 1-1/2753 “Щодо реформування системи охорони здоров’ я, спрямованого на підвищення якості і доступності медичної допомоги для громадян України" та наказу МО3 України від 03.12.2010 № 1074 "Про заходи МО3 України щодо удосконалення підготовки лікарів", Міністерством затверджено Наскрізну програму підготовки студентів медичних факультетів

(ㄱ О. П. Волосовець, Ю. С. П’ятницький, І. С. Вітенко та ін. 
та лікарів-інтернів для оволодіння практичними навичками та методиками, необхідними для роботи на посадах лікарів за спеціальністю “Загальна практика - сімейна медицина” (далі - Наскрізна програма). Програму розроблено фахівцями Тернопільського державного медичного університету імені I. Я. Горбачевського, прорецензовано спеціалістами профільних кафедр Національного медичного університету імені О. О. Богомольця та Національної медичної академії післядипломної освіти імені П. Л. Шупика [3]. Підготовлений перелік практичних навичок та методик відповідає завданням щодо підготовки сімейного лікаря та специфіці його роботи.

Наказом МО3 України від 11.11.2011 № 782 “Про впровадження Рішення наради ректорів вищих медичних (фармацевтичного) навчальних закладів IV рівня акредитації та закладів післядипломної освіти MO3 України “Підсумки проведення вступної кампанії до вищих навчальних закладів МО3 України у 2011 році. Актуальні питання поліпшення якості та організації підготовки медичних та фармацевтичних спеціалістів" від 11.10.2011" ректорам ВМН3 IV рівня акредитації було доручено запровадити зазначену Програму в навчальний процес, розробити та затвердити на вчених радах План заходів щодо впровадження та контролю за виконанням Наскрізної програми підготовки студентів медичних факультетів вищих медичних навчальних закладів IV рівня акредитації та лікарів-інтернів для оволодіння практичними навичками й методиками, необхідними для робо-

\section{Лiтература}

1. Лист МОЗ України від 18.04.2011 № 08.01-47/706 щодо впровадження у навчальну роботу ВНМЗ Наскрізної програми підготовки студентів медичних факультетів вищих медичних навчальних закладів IV рівня акредитації та лікарівінтернів для оволодіння практичними навичками та методиками, необхідними для роботи на посадах лікарів за спеціальністю “Загальна практика - сімейна медицина”.

2. Лист МОЗ України від 06.06.2011 № 08.01 - 47/895 щодо впровадження у навчально-виховний процес ВМНЗ рішення Всеукраїнської наукової навчально-методичної конференції “Нові напрямки впровадження кредитно-модульної системи організації навчального процесу у вищих медичних і фармацевтичному навчальних закладах України III-IV рівнів акредитації' (12-13 травня 2011 року, м. Тернопіль).

3. Матеріали Всеукраїнської наукової навчально-методичної конференції “Нові напрямки впровадження кредитно-модульної системи організації навчального процесу у вищих медичних і фармацевтичному навчальних закладах України III-IV рівнів акредитації” (12-13 травня 2011 року, м. Тернопіль). - Тернопіль : ТДМУ, 2011. -566 с. ти на посадах лікарів за спеціальністю “Загальна практика - сімейна медицина”, форму індивідуального обліку засвоєння студентами 4-6 курсів та лікарями-інтернами за фахом "Загальна практика - сімейна медицина” практичних навичок і методик, передбачених Наскрізною програмою, встановивши її як засіб контролю за виконанням індивідуального навчального плану студента (лікаря-інтерна) [4]. Як зазначено у вказаній програмі, контролем оволодіння практичних навичок та необхідних для обстеження хворих методик буде оцінка заповнення відповідної медичної документації, захист карт амбулаторного хворого, карт диспансерного спостереження, демонстрація практичних навичок на фантомах та хворих [5].

Висновок. Міністерство охорони здоров'я України вважає за доцільне обговорити на сумісному засіданні Координаційної науково-методичної ради 3 вищої медичної освіти та Координаційної науково-методичної ради з післядипломної освіти МОЗ України запропоновані навчальними закладами варіанти форм індивідуального обліку засвоєння студентами та лікарями-інтернами практичних навичок та методик, передбачених Наскрізною програмою. За результатами обговорення буде визначено доцільність підготовки та затвердження в установленому порядку уніфікованої для всіх вищих медичних навчальних закладів IV рівня акредитації форми індивідуального обліку засвоєння студентами та лікарями-інтернами практичних навичок і методик.

4. Наказ МОЗ України від 11.11.2011 № 782 “Про впровадження Рішення наради ректорів вищих медичних (фармацевтичного) навчальних закладів IV рівня акредитації та закладів післядипломної освіти MO3 України “Підсумки проведення вступної кампанії до вищих навчальних закладів МО3 України у 2011 році. Актуальні питання поліпшення якості та організації підготовки медичних та фармацевтичних спеціалістів" від 11.10.2011".

5. Наскрізна програма підготовки студентів медичних факультетів вищих медичних навчальних закладів IV рівня акредитації та лікарів-інтернів для оволодіння практичними навичками та методиками, необхідними для роботи на посадах лікарів за спеціальністю “Загальна практика-сімейна медицина”. - Київ, 2011.-16 с.

6. Систематизація навчально-методичної роботи в контексті Болонського процесу на кафедрах післядипломної освіти вищих медичних медичних навчальних закладів III-IV рівнів акредитації : навчальний посібник / за ред. Є. Х. Заремби. - Львів, 2009. - 189 с. 